ISSN 1392-3196 / e-ISSN 2335-8947

Zemdirbyste-Agriculture, vol. 101, No. 1 (2014), p. 67-74

DOI 10.13080/z-a.2014.101.009

\title{
Mulch type and application of manure and composts in strawberry (Fragaria $\times$ ananassa Duch.) production: impact on soil fertility and yield
}

\author{
Ranko CABILOVSKI ${ }^{1}$, Maja MANOJLOVIC ${ }^{1}$, Darinka BOGDANOVIC ${ }^{1}$, \\ Nenad MAGAZIN ${ }^{1}$, Zoran KESEROVIC ${ }^{1}$, Bishal K. SITAULA ${ }^{2}$ \\ ${ }^{1}$ University of Novi Sad \\ Trg Dositeja Obradovica 8, Novi Sad, Serbia \\ E-mail: ranko@polj.uns.ac.rs \\ ${ }^{2}$ Norvegian University of Life Sciences \\ Ås, Norway
}

\begin{abstract}
The objective of this research was to quantify the effect of the application of organic fertilizers: farmyard manure, vermicompost, spent mushroom compost, under two different ground cover management systems (black polyethylene and wheat straw mulch) on soil nutrient levels and strawberry yield during a two-year production cycle. The application of organic fertilizers, in the amounts equivalent to $170 \mathrm{~kg} \mathrm{ha}^{-1} \mathrm{~N}$, had the greatest impact on the concentration of available phosphorus, which was significantly higher on fertilized plots than on the control even two years after the application. The plots fertilized with farmyard manure and mushroom compost had higher concentrations of available potassium than the control, while the application of vermicompost did not affect the concentration of available potassium in the soil. The application of composts did not affect the concentration of available microelements in the soil, while the concentrations of $\mathrm{Fe}, \mathrm{Zn}$ and $\mathrm{Cu}$ in the year of the organic fertilizers application were significantly higher on farmyard manure fertilized plots than on the control. The application of all three organic fertilizers had a significant effect on the mineral $\mathrm{N}$ concentration in the soil only in the year of the application and the following spring. However, the plots covered with polyethylene mulch had a higher mineral $\mathrm{N}$ concentration than the control at all sampling times. The concentration of available microelements was significantly higher in soil covered with black polyethylene mulch than in soil covered with straw mulch. Preplant application of organic fertilizers led to increase of yield, ranging from $14.3 \%$ in vermicompost treatmet to $17.3 \%$ in the farmyard manure treatment in relation to the control, only in the $1^{\text {st }}$ fruiting year. However, the application of polyethylene mulch facilitated a higher strawberry yield than straw mulch in both fruiting years.
\end{abstract}

Key words: nutrient availability, organic fertilizer, residual effects.

\section{Introduction}

Growing environmental concern and spreading of production systems such as organic, biodynamic or sustainable agriculture, where the usage of synthetic fertilizers is limited or completely excluded, has led to increased public and scientific attention to organic fertilization. The application of organic fertilizers not only supplies the plants with necessary elements but also plays an important part in the process of enhancing soil fertility by improving its structure and hydro-physical properties, increasing organic matter concentration and reducing the application of synthetic fertilizers (Grandy et al., 2002). Unlike mineral fertilizers, organic fertilizers have a longer-lasting impact on chemical properties of the soil and consequently on the yield of grown crops, even several years after application (Gutser et al., 2005). Depending on their chemical composition, organic fertilizers mineralize at different rates (De Neve et al., 2004), which is why their effectiveness as sources of nutrients is also different (Pansu, Thuries, 2003). Uncontrolled and excessive use of organic fertilizers can lead to adverse effects such as nitrogen $(\mathrm{N})$ leaching into ground water, release of heavy metals and harmful organic substances into soil, spread of weeds, soil pollution with harmful microorganisms, etc. This is why EC Regulation $1804 / 1999$ of organic production and Nitrates Directive (Council Directive 91/676/EEC, 1991) limit the maximum annual incorporation of organic fertilizers to the amount equivalent to $170 \mathrm{~kg} \mathrm{ha}^{-1} \mathrm{~N}$.

Due to its low height and shallow root, strawberry is one of the fruit species most sensitive to weeds (Johnson, Fennimore, 2005). Since in strawberry production it is necessary to suppress weeds during the whole vegetation period, which requires a high number of man-hours and increases production costs, especially in organic systems, where the application of herbicides is not allowed, one solution was to cover the soil with different 
types of mulch. Mulching in strawberry production not only has a positive effect in weed management but, depending on the sort of material used, can have other effects on the crop and physical and chemical properties of the soil (Neuweiler et al., 2003; Obalum, Obi, 2010).

Plowing under organic fertilizers in autumn is a common method of their application (Smith et al., 2001). However, the results of some authors (Hansen et al., 2004) show that spring application of organic fertilizers, due to better synchronization of crops needs and the release of nutrients has a greater impact on crop yield in the year of application. If strawberry is grown as a perennial crop, on the same plot for two or three consecutive years, the only opportunity to apply solid organic fertilizers is at planting time, which in agroecological conditions in Serbia commonly occurs in the second half of the year (July-August).

The objective of this research was to quantify the effect of the application of organic fertilizers in amounts equivalent to $170 \mathrm{~kg} \mathrm{ha}^{-1} \mathrm{~N}$ at strawberry planting time on the chemical properties of the soil and strawberry yield during a two-year production cycle, under two different ground cover management systems.

\section{Materials and methods}

Experimental site. The studies were conducted at Research Field for Fruit Growing of the Faculty of Agriculture, University of Novi Sad, Serbia $\left(45^{\circ} 20^{\prime} 24.44^{\prime \prime}\right.$ N, 19 $50^{\prime} 22.32^{\prime \prime}$ E) from 2009 to 2011. The soil of the experimental site is Haplic Phaeozem (PHh), formed on loess terrace, which is the main soil type in Vojvodina (northern part of Serbia), covering 60\% of agricultural land. The experiment plot had not been fertilized for the previous five years, and the basic physical and chemical properties of the soil were as follows: $1.26 \mathrm{~g}$ $\mathrm{cm}^{-3}$ bulk density, $0.27 \%$ coarse sand, $40.0 \%$ fine sand,
$35.9 \%$ silt, $23.8 \%$ clay, $\mathrm{pH} 7.92$ (in $\mathrm{H}_{2} \mathrm{O}$ ), $0.83 \% \mathrm{CaCO}_{3}$, $2.05 \%$ organic C, $0.181 \%$ total N, $11.32 \mathrm{C}: \mathrm{N}, 57 \mathrm{mg}$ $\mathrm{kg}^{-1} \mathrm{AL}-\mathrm{P}_{2} \mathrm{O}_{5}, 215 \mathrm{mg} \mathrm{kg}^{-1} \mathrm{AL}-\mathrm{K}_{2} \mathrm{O}$. The concentrations of available micronutrients in the soil extracted with diethylenetriaminepentaacetic acid-triethanolamine (DTPA-TEA) were: $2.06 \mathrm{mg} \mathrm{kg}^{-1} \mathrm{Fe}, 18.56 \mathrm{mg} \mathrm{kg}^{-1} \mathrm{Mn}$, $0.89 \mathrm{mg} \mathrm{kg}^{-1} \mathrm{Cu}$ and $1.26 \mathrm{mg} \mathrm{kg}^{-1} \mathrm{Zn}$. The experiment was conducted in the conditions of drip irrigation, without any additional fertilization during the growing seasons. The drip irrigation system was operated periodically during the period April-September (in each year) to maintain soil moisture tension between 15 and $25 \mathrm{kPa}$ (measured by a tensiometer with the ceramic tip at $15 \mathrm{~cm}$ below the surface of the bed between two plants in a row). The total monthly precipitation and average air temperature during the experiment are given in Figure 1.

Experimental design and treatments. The experiment was conducted using a two-factorial splitplot completely randomized design, with ground cover management (mulch) as whole-plot factor and fertilization treatments in split-plots. Each split-plot consisted of ten uniform June-bearing strawberry (Fragaria $\times$ ananassa Duch.) plants cultivar 'Senga Sengana' in four replicates. Besides the control treatment (no fertilization), three different organic fertilizers: farmyard manure, vermicompost and spent compost from mushroom production, were incorporated into the surface soil layer $(0-30 \mathrm{~cm})$ one week before strawberry planting (23 July, 2009). Organic fertilizers were applied in amounts which were equivalent to $170 \mathrm{~kg} \mathrm{ha}^{-1} \mathrm{~N}$. The chemical compositions of the applied organic fertilizers are presented in Table 1.

Two lateral drip lines with drippers providing water $\left(2 \mathrm{dm}^{-3} \mathrm{~h}^{-1}\right)$ were installed and $50 \mu \mathrm{m}$-thick black polyethylene mulch and wheat straw were applied to cover the entire surface around the strawbery plants. The experiment was set up on raised beds $0.8 \mathrm{~m}$ wide and $15 \mathrm{~cm}$ high.
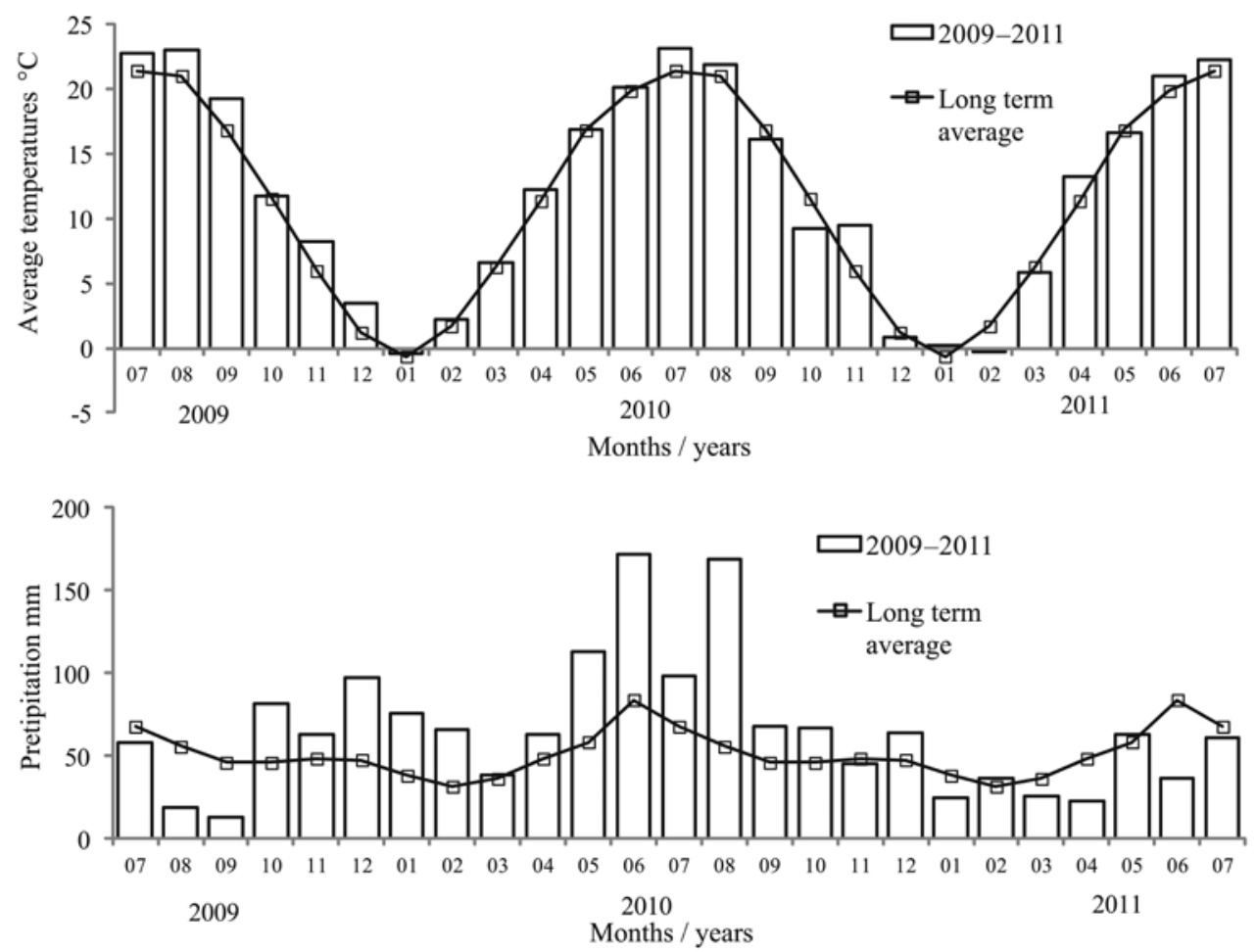

Figure 1. Total monthly precipitation and monthly average air temperature (2009-2011) 
Table 1. Chemical composition of the organic fertilizers used in the experiment

\begin{tabular}{|c|c|c|c|}
\hline \multirow{2}{*}{$\begin{array}{l}\text { Chemical } \\
\text { properties }\end{array}$} & \multicolumn{3}{|c|}{ Organic fertilizers } \\
\hline & vermicompost & $\begin{array}{c}\text { mushroom } \\
\text { compost }\end{array}$ & $\begin{array}{c}\text { farmyard } \\
\text { manure }\end{array}$ \\
\hline Dry mater \% & 75.46 & 80.26 & 71.36 \\
\hline $\mathrm{pH}\left(\right.$ in $\left.\mathrm{H}_{2} \mathrm{O}\right)$ & 7.56 & 6.92 & 7.72 \\
\hline Total N \% & 1.99 & 1.65 & 1.71 \\
\hline Total C \% & 25.2 & 18.37 & 32.5 \\
\hline $\mathrm{C}: \mathrm{N}$ & 12.7 & 11.13 & 19.01 \\
\hline Total $\mathrm{P}_{2} \mathrm{O}_{5} \%$ & 3.02 & 2.27 & 2.03 \\
\hline Total $\mathrm{K}_{2} \mathrm{O} \%$ & 1.26 & 1.81 & 2.81 \\
\hline Fe mg kg-1 & 1054 & 1342 & 986 \\
\hline Mn mg kg-1 & 171 & 230 & 126 \\
\hline $\mathrm{Cu} \mathrm{mg} \mathrm{kg-1}$ & 8.9 & 26.8 & 5.54 \\
\hline $\mathrm{Zn} \mathrm{mg} \mathrm{kg-1}$ & 45.2 & 53 & 35.8 \\
\hline
\end{tabular}

Measurements and analytical determination. The $\mathrm{pH}$ value of the soil was determined in a suspension of soil and $\mathrm{H}_{2} \mathrm{O}(1: 2.5)$ using a meter Metrel MA 3657 $\mathrm{pH}$ ("Metrel", Slovenia). $\mathrm{CaCO}_{3}$ content was determined volumetrically using a Scheibler calcimeter (HEDAS, Serbia). Total $\mathrm{N}$ and $\mathrm{C}$ content in soil was determined using an analyzer CHNS ("Elementar Vario EL", Germany). Plant-available phosphorus (P) and potassium $(\mathrm{K})$ in the soil were extracted with a solution of $0.1 \mathrm{M}$ ammonium lactate and $0.4 \mathrm{M}$ acetic acid $(\mathrm{pH} 3.75)$, at a soil to solution ratio of $1: 20(\mathrm{w} / \mathrm{v})$. The concentration of $\mathrm{P}$ was measured by spectrophotometry, while the concentration of $\mathrm{K}$ was measured by flame photometry. Mineral $\mathrm{N}$ concentration under field conditions during the vegetation was determined by the Wehrmann and Scharpf (1979) method. For the determination of plant-available fractions of $\mathrm{Fe}, \mathrm{Mn}, \mathrm{Cu}$ and $\mathrm{Zn}$ in the soil, samples were extracted with diethylenetriaminepentaacetic acidtriethanolamine (DTPA-TEA) buffer solution $(0.005 \mathrm{M}$ $\mathrm{DTPA}+0.01 \mathrm{M} \mathrm{CaCl}_{2}+0.1 \mathrm{M}$ TEA). For each sample, $20 \mathrm{~mL}$ of DTPA-TEA solution was added to $10.0 \mathrm{~g}$ of soil, shaken for $2 \mathrm{~h}$ on an orbital shaker, gravity filtered through filter paper, and analyzed by atomic absorption spectrometer "Shimadzu 6300" (Japan) with flame technique. Dry matter content of organic fertilizer was determined gravimetrically $\left(70^{\circ} \mathrm{C}\right.$ for $\left.24 \mathrm{~h}\right)$. Total $\mathrm{C}$ and $\mathrm{N}$ contents were determined using an analyzer CHNS. After wet-digestion with a mixture of $\mathrm{HNO}_{3}: \mathrm{HCIO}_{4}$ $(4: 1, v / v)$, the concentrations of $\mathrm{K}, \mathrm{Fe}, \mathrm{Mn}, \mathrm{Cu}$ and $\mathrm{Zn}$ concentrations in the organic fertilizer were determined using an atomic absorption spectrometer "Shimadzu 6300" with flame technique, while $\mathrm{P}$ concentration in the solutions was measured colorimetrically by spectrophotometer "Jenway 6105" (USA). Soil samples used to determine mineral $\mathrm{N}$, available $\mathrm{P}$ and available $\mathrm{K}$ contents in the soil during strawberry vegetation consisted of two individual samples taken from every treatment repetition. The samples were taken two months after organic fertilizer application (10 October, 2009), and subsequently in spring, summer and autumn in 2010 (28 March, 10 June, 8 October), and spring and summer in 2011 (31 March, 6 June). The concentrations of available microelements ( $\mathrm{Fe}, \mathrm{Mn}, \mathrm{Zn}$ and $\mathrm{Cu}$ ) were determined in the samples taken two months after organic fertilizer application (autumn 2009), in summer 2010, and in summer 2011.
Total number of flowers was measured at the end of flowering of secondary flower series (12 April, 2010 and 16 April, 2011) by counting the flowers buds, open flowers and small-green fruits on three randomly selected plants per replicates. Total fruit yield was calculated by taking all the harvested fruit and thereafter, randomly selected 30 normal fruits (subsample), taken from each replicate at each harvest time, were used to calculate mean berry weight.

Statistical analysis. The results were subjected to analysis of variance (ANOVA) according to their experimental design, and treatment means were compared using the Turkey test $(P<0.05)$ with STATISTICA 9 (StatSoft Inc., USA).

\section{Results and discussion}

Fertilization and mulch impact on concentrations of available $N, P$ and $K$ in the soil. Two months after the organic fertilizer application, in October 2009 , the concentration of mineral forms of $\mathrm{N}\left(\mathrm{NH}_{4}-\mathrm{N}\right.$ and $\mathrm{NO}_{3}-\mathrm{N}$ ) in the soil was significantly higher on the plots treated with organic fertilizer than on the control, and it ranged from 18 to $24.23 \mathrm{mg} \mathrm{kg}^{-1} \mathrm{~N}$ of the soil. In 2010 (the $1^{\text {st }}$ fruiting year), mineral $\mathrm{N}$ concentration in the soil on the fertilized plots was significantly higher than the control only at the first sampling time, while in 2011 mineral $\mathrm{N}$ concentration on the fertilized plots did not differ significantly from the control. Significant differences among individual fertilization treatments were found only at first sampling time (October 2009), when mineral $\mathrm{N}$ concentration in the soil treated with farmyard manure was significantly higher than in vermicompost treatment, while at the other sampling times no significant differences were found (Fig. 2). After organic fertilizers are incorporated into the soil, the process of mineralization releases mineral forms of $\mathrm{N}$ and $\mathrm{P}$. Because of their favourable chemical composition and primarily because of their $\mathrm{C}: \mathrm{N}$ and C:P ratios (Gutser et al., 2005), all the three organic fertilizers released mineral forms of $\mathrm{N}$ and $\mathrm{P}$ in the year of application. However, the residual effect of the organic fertilizer on mineral $\mathrm{N}$ concentration was significant only at the first sampling time the following year (Fig. 2). Relatively short-lasting residual effect can be explained by the fact that the total amounts of applied fertilizers $\left(170 \mathrm{~kg} \mathrm{ha}^{-1} \mathrm{~N}\right)$ are relatively low when compared to those used by other authors (Ginting et al., 2003; Gutser et al., 2005), who obtained significantly longer-lasting effects of organic fertilizer application on mineral $\mathrm{N}$ concentration.

In the present study the fertilizers were applied in the second half of summer, when temperatures were very favourable for mineralization (Fig. 1). As soil humidity was maintained at $70-80 \%$ of field water capacity, most of $\mathrm{N}$ in organic fertilizer was mineralized in the year of application. Eghball (2000) suggests that only $11 \%$ of organic $\mathrm{N}$ from composted manure and $21 \%$ from noncomposted manure applied in autumn mineralized in the following year. Besides, a large amount of precipitation in the first half of 2010 could cause part of mineral $\mathrm{N}$ to run off into deeper layers of the soil, beyond the plants' root zone (Fig. 1), so the differences among individual fertilizer treatments from the second sampling time in 2010 till the end of the experiment were not statistically significant. 

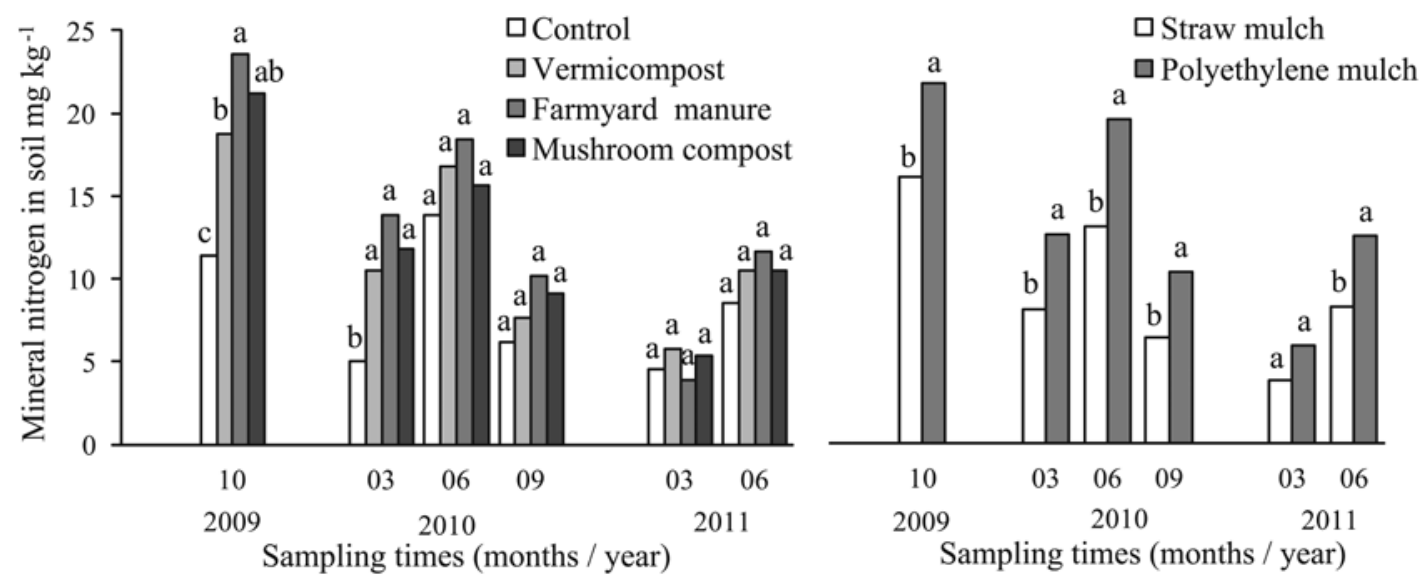

Note. Within one sampling time, values followed by different letters are significantly different at $P<0.05$.

Figure 2. Concentration of mineral nitrogen $\left(\mathrm{NH}_{4}-\mathrm{N}\right.$ and $\left.\mathrm{NO}_{3}-\mathrm{N}\right)$ in the soil $(0-30 \mathrm{~cm})$

From the first sampling time through to the end of the experiment, concentration of available $\mathrm{P}$ was higher on fertilized plots than on the control treatment. At the same time, only at some sampling times (October 2009 and June 2010) P concentration on the farmyard manure fertilized plot was significantly higher than on that fertilized with mushroom compost (Fig. 3).

Through the application of organic fertilizer different amounts of $\mathrm{P}$ were introduced into the soil (203 kg ha-1 $\mathrm{P}_{2} \mathrm{O}_{5}$, farmyard manure, $233 \mathrm{~kg} \mathrm{ha}^{-1} \mathrm{P}_{2} \mathrm{O}_{5}$, mushroom compost, $256 \mathrm{~kg} \mathrm{ha}^{-1} \mathrm{P}_{2} \mathrm{O}_{5}$, vermicompost). Due to a good C:P (Dao, Schwartz, 2010) of all three organic fertilizers, significant amounts of available $\mathrm{P}$ were released into the soil, but, unlike N, P concentration was significantly higher on fertilized plots than on the control even at the last sampling time (two years after the application of the organic fertilizer). This can be explained by the fact that fertilization introduced more $\mathrm{P}$ than $\mathrm{N}$ into the soil (Table 1), while $\mathrm{N}$ uptake by strawberry plants can be up to five times higher than $\mathrm{P}$ uptake (Tagliavini et al., 2005). Besides, the mobility of available forms of $\mathrm{N}$ in the soil is greater than that of $\mathrm{P}$ so possible losses are also greater (Zeng et al., 2008). Mohammadi et al. (2009) observed prolonged effects of available P five years after the application of organic fertilizers. Higher concentrations of available $\mathrm{P}$ on the plots fertilized with farmyard manure than on the plots fertilized with composts are probably caused by different availability of $P$ in these fertilizers. Eghbal (2000) reports, that $\mathrm{P}$ availability in the first year after application was $85 \%$ for beef cattle manure and $73 \%$ for composted feedlot manure. Slightly lower P availability from composted manure indicates a chemical reaction of $\mathrm{P}$ during composting, which caused $\mathrm{P}$ to become less plant-available.

Mulching had a greatest impact on the concentrations of mineral forms of $\mathrm{N}$ in the soil. For the duration of the experiment, except in spring 2011 ( $2^{\text {nd }}$ fruiting year), mineral $\mathrm{N}$ concentrations on the polyethylene mulched plots were significantly higher than on the straw mulched ones (Fig. 2). However, polyethylene mulching had a positive effect on available

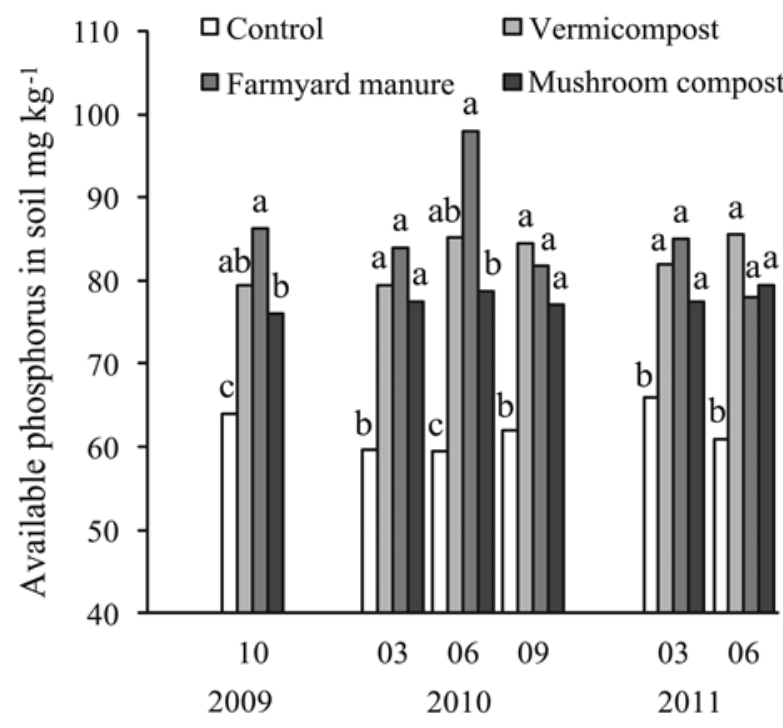

Sampling times (months / years)
口Straw mulch

$\square$ Polyethylene mulch

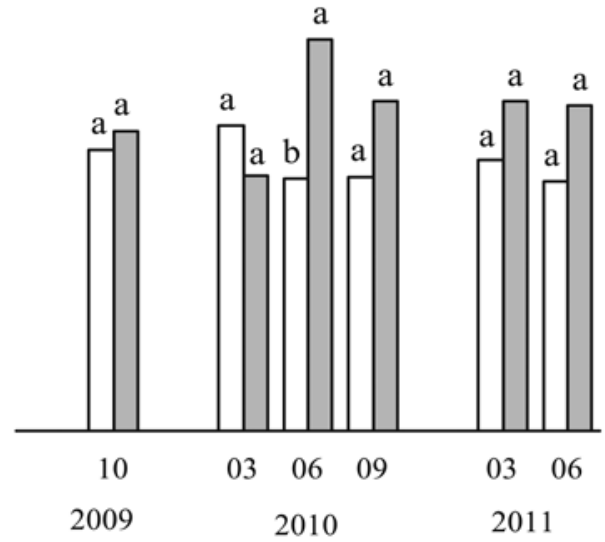

Sampling times (months / years)

Explanation under Figure 2

Figure 3. Concentration of available phosphorus $\left(\mathrm{P}_{2} \mathrm{O}_{5}\right)$ in the soil $(0-30 \mathrm{~cm})$ 
$\mathrm{P}$ concentrations in the soil only at one sampling time (summer 2010); while at all the other sampling times there were no significant differences between the individual treatments (Fig. 3).

In our research, the application of organic fertilizers had a positive effect on the concentration of available $\mathrm{K}$ in the soil, which is in agreement with findings of Wen et al. (1997). They reported that K in composted manure is $100 \%$ plant available, while Motavalli et al. (1989) indicated a somewhat lower figure $(73 \%$ on average) for injected dairy manure. However, concentrations of available $\mathrm{K}$ that were significantly higher than the control were recorded on the plots fertilized with farmyard manure and mushroom compost, while the application of vermicompost did not significantly affect the concentration of available $\mathrm{K}$ in the soil (Fig. 4). Through the application of organic fertilizers in such amounts as to introduce $170 \mathrm{~kg} \mathrm{ha}^{-1} \mathrm{~N}$, the soil received different amounts of $\mathrm{K}$ (Table 1 ). Through the application of farmyard manure, $318 \mathrm{~kg} \mathrm{ha}^{-1} \mathrm{~K}_{2} \mathrm{O}$ was incorporated into the soil, which is about $200 \mathrm{~kg} \mathrm{ha}^{-1} \mathrm{~K}_{2} \mathrm{O}$ more than through the application of vermicompost and $120 \mathrm{~kg}$ more than mushroom compost, which may be a reason for the fact that the concentrations of available $\mathrm{K}$ with farmyard manure treatment were significantly higher than with the other treatments throughout the experiment (Fig. 4).

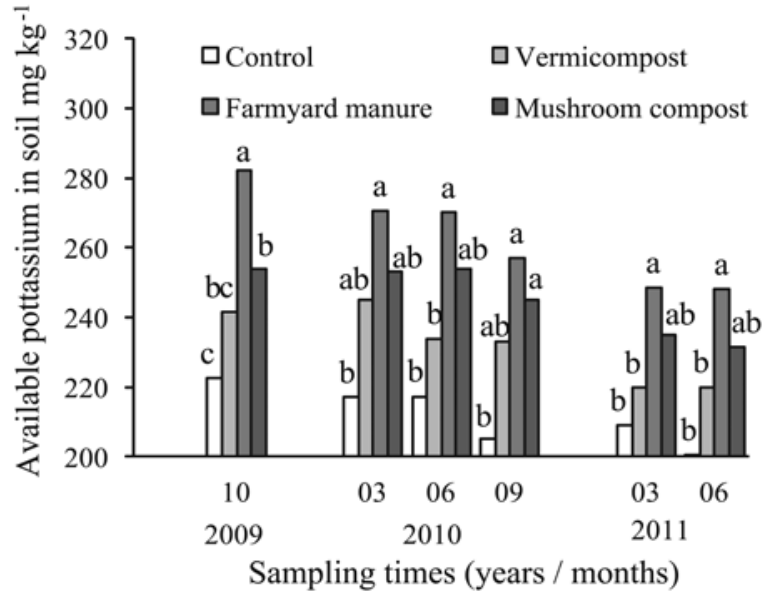

口Straw mulch

口Polyethylene mulch

2

Explanation under Figure 2

Figure 4. Concentration of available potassium $\left(\mathrm{K}_{2} \mathrm{O}\right)$ in the soil $(0-30 \mathrm{~cm})$

Mulching did not affect available $\mathrm{K}$ concentrations in our experiment. Polyethylene mulch could have positively affected the temperature of the soil (Ghosh et al., 2006) and reduced evaporation (Li et al., 2013), which created more favourable conditions for the mineralization of organic matter and release of higher amounts of mineral N, than was the case with straw mulch. Our results are in agreement with those of Neuweiler et al. (2003), who also found a significantly lower mineral $\mathrm{N}$ concentration on straw mulched plots than on those covered with polyethylene mulch. However, available $\mathrm{K}$ concentration was not affected by mulch (Fig. 4), while available $\mathrm{P}$ concentration in soil was significantly higher under polyethylene mulch only in summer 2010, when the difference in $\mathrm{pH}$ values between different mulches was highest ( $0.37 \mathrm{pH}$ units).

Organic fertilization and mulch impact on micronutrients availability and soil $\mathbf{p H}$. In the present study the application of organic fertilizer did not affect $\mathrm{pH}$ values of the soil (Table 2). Other studies have found a significant decrease (Chang et al., 2007), or increase (Zaller, Koepke, 2004) in soil pH with long-term application of organic fertilizer, depending on initial soil $\mathrm{pH}$. However, our results are in agreement with Mohammadi et al. (2009), who reported that differences in $\mathrm{pH}$ were not significant for one- and two-year applications of organic fertilizer when compared to the control, probably because of the buffering capacity of the soil. On the other hand, $\mathrm{pH}$ values on the polyethylene mulched plots were significantly lower than those of straw mulched plots during the first two years of the research (Table 2). Two months after the application of farmyard manure, the concentrations of available forms of $\mathrm{Fe}, \mathrm{Zn}$ and $\mathrm{Cu}$ were significantly higher than the control treatment. Although the application of composts did increase the concentrations of available forms of microelements in relation to the control, the differences were not significant (Table 2). In 2009 and 2010, the concentrations of available forms of microelements were significantly higher on plots covered with polyethylene mulch than on those covered with straw mulch, while in 2011 no significant differences were found (Table 2).

Even though the organic fertilizers used in the present research had relatively similar total micronutrient concentrations (Table 1), the application of composts did not affect the concentration of available micronutrients in the soil, while in the farmyard manure treatment in the first year of application (2010), the concentrations of $\mathrm{Fe}, \mathrm{Cu}$ and $\mathrm{Zn}$ were significantly higher than the control. Richards et al. (2011) found that the application of fertilizers for several years significantly increased organic matter content and the concentrations of available forms of $\mathrm{Fe}, \mathrm{Cu}, \mathrm{Mn}, \mathrm{Zn}$ and $\mathrm{Mo}$ in the soil and also find significant correlations between total amounts of micronutrients applied through organic fertilizer and available forms of those micronutrients in the soil. As organic fertilizer did not impact soil $\mathrm{pH}$, which greatly affects the availability of micronutrients, the increase of micronutrient concentrations is probably a result of the interaction between metal ions and various organic acids created during the mineralization of applied organic matter, and formation of chelated complexes (Leita et al., 
Table 2. Soil $\mathrm{pH}$ and concentrations of available micronutrients in the soil $\left(\mathrm{mg} \mathrm{kg}^{-1}\right)$

\begin{tabular}{|c|c|c|c|c|c|}
\hline & \multicolumn{5}{|c|}{2009 (planting year) } \\
\hline Fertilization & $\mathrm{pH}$ & $\mathrm{Fe}$ & $\mathrm{Mn}$ & $\mathrm{Zn}$ & $\mathrm{Cu}$ \\
\hline Control & $7.76 \mathrm{a}$ & $2.19 \mathrm{~b}$ & $20.63 \mathrm{a}$ & $1.34 \mathrm{~b}$ & $1.13 \mathrm{~b}$ \\
\hline Vermicompost & $7.80 \mathrm{a}$ & $2.76 \mathrm{ab}$ & $21.59 \mathrm{a}$ & $1.59 \mathrm{ab}$ & $1.43 \mathrm{ab}$ \\
\hline Mushroom compost & $7.75 \mathrm{a}$ & $2.50 \mathrm{ab}$ & $21.14 \mathrm{a}$ & $1.37 \mathrm{~b}$ & $1.36 \mathrm{ab}$ \\
\hline \multicolumn{6}{|l|}{ Mulching } \\
\hline Polyethylene mulch & $7.67 \mathrm{~B}$ & $2.83 \mathrm{~A}$ & $23.25 \mathrm{~A}$ & $1.72 \mathrm{~A}$ & $1.54 \mathrm{~A}$ \\
\hline \multirow[t]{2}{*}{ Straw mulch } & $7.84 \mathrm{~A}$ & $2.14 \mathrm{~B}$ & $19.25 \mathrm{~B}$ & $1.37 \mathrm{~B}$ & $1.25 \mathrm{~B}$ \\
\hline & \multicolumn{5}{|c|}{$2010\left(1^{\text {st }}\right.$ fruiting year $)$} \\
\hline Fertilization & $\mathrm{pH}$ & $\mathrm{Fe}$ & $\mathrm{Mn}$ & $\mathrm{Zn}$ & $\mathrm{Cu}$ \\
\hline Control & $7.46 \mathrm{a}$ & $3.42 \mathrm{a}$ & $27.98 \mathrm{a}$ & $1.90 \mathrm{a}$ & $2.53 \mathrm{a}$ \\
\hline Vermicompost & $7.54 \mathrm{a}$ & $3.83 \mathrm{a}$ & $29.00 \mathrm{a}$ & $2.16 \mathrm{a}$ & $2.82 \mathrm{a}$ \\
\hline Mushroom compost & $7.49 \mathrm{a}$ & $3.56 \mathrm{a}$ & $28.61 \mathrm{a}$ & $2.28 \mathrm{a}$ & $2.68 \mathrm{a}$ \\
\hline $\begin{array}{c}\text { Farmyard manure } \\
\text { Mulching }\end{array}$ & $7.52 \mathrm{a}$ & $3.81 \mathrm{a}$ & $28.21 \mathrm{a}$ & $2.20 \mathrm{a}$ & $2.90 \mathrm{a}$ \\
\hline Polyethylene mulch & $7.35 \mathrm{~B}$ & $4.36 \mathrm{~A}$ & $33.06 \mathrm{~A}$ & $2.31 \mathrm{~A}$ & $3.30 \mathrm{~A}$ \\
\hline \multirow[t]{2}{*}{ Straw mulch } & $7.65 \mathrm{~A}$ & $3.08 \mathrm{~B}$ & $24.37 \mathrm{~B}$ & $1.87 \mathrm{~B}$ & $2.08 \mathrm{~B}$ \\
\hline & \multicolumn{5}{|c|}{2011 ( $2^{\text {nd }}$ fruiting year $)$} \\
\hline Fertilization & $\mathrm{pH}$ & $\mathrm{Fe}$ & $\mathrm{Mn}$ & $\mathrm{Zn}$ & $\mathrm{Cu}$ \\
\hline Control & $7.58 \mathrm{a}$ & $3.15 \mathrm{a}$ & $25.07 \mathrm{a}$ & $2.34 \mathrm{a}$ & $2.03 \mathrm{a}$ \\
\hline Vermicompost & $7.68 \mathrm{a}$ & $3.40 \mathrm{a}$ & $25.44 \mathrm{a}$ & $2.28 \mathrm{a}$ & $1.98 \mathrm{a}$ \\
\hline Mushroom compost & $7.64 \mathrm{a}$ & $3.10 \mathrm{a}$ & $26.78 \mathrm{a}$ & $2.33 \mathrm{a}$ & $1.93 \mathrm{a}$ \\
\hline $\begin{array}{c}\text { Farmyard manure } \\
\text { Mulching }\end{array}$ & $7.62 \mathrm{a}$ & $3.38 \mathrm{a}$ & $26.54 \mathrm{a}$ & $2.50 \mathrm{a}$ & $1.78 \mathrm{a}$ \\
\hline Polyethylene mulch & $7.58 \mathrm{~A}$ & $3.34 \mathrm{~A}$ & $26.95 \mathrm{~A}$ & $2.31 \mathrm{~A}$ & $1.98 \mathrm{~A}$ \\
\hline Straw mulch & $7.67 \mathrm{~A}$ & $3.19 \mathrm{~A}$ & $28.90 \mathrm{~A}$ & $2.22 \mathrm{~A}$ & $2.24 \mathrm{~A}$ \\
\hline
\end{tabular}

Notes. * - values followed by different upper- (mulching) and lowercase (fertilization) letters are statistically significantly different at $p<0.05$. Interactions mulch $\times$ fertilization were not statistically significant.

1999). Eghball et al. (1997) remark that in comparison to farmyard manure, a considerable part of readily degradable organic $\mathrm{C}$ and $\mathrm{N}$ in composts is lost during composting, while remaining $\mathrm{C}$ and $\mathrm{N}$ are found in more stable forms which are more resistant to mineralization and have weaker affinity to metal ions in the creation of chelated complexes. Besides this, by applying farmyard manure significantly more organic $\mathrm{C}$ was incorporated into the soil than was the case with compost (mushroom compost and vermicompost) treatments (Table 2), which could also have led to farmyard manure having a higher impact on available micronutrient concentrations than composts (Richards et al., 2011). The differences between the two mulching methods could have arisen from higher soil temperatures, more intensive mineralization (Fig. 2) and the creation of larger amounts of organic acids and $\mathrm{CO}_{2}$ under polyethylene mulch (Moreno, Moreno, 2008). As polyethylene mulch is considerably less gas permeable than straw, this may have caused higher amounts of $\mathrm{CO}_{2}$ to remain in the soil and led to the formation of carbonic acid, which in turn resulted in lower soil $\mathrm{pH}$. This is why at first two sampling times (2009 and 2010), due to a lower soil $\mathrm{pH}$ value, the concentrations of available forms of all four micronutrients were significantly higher in the soils covered with polyethylene mulch than in those covered with straw mulch.

Strawberry yield. In the $1^{\text {st }}$ fruiting year (2010), the application of all three organic fertilizers had a considerable impact on the total number of flowers per plant and total strawberry yield. The total yield on fertilized plots was $118 \mathrm{~g} \mathrm{plant}^{-1}$ (vermicompost) to 150 g plant $^{-1}$ (farmyard manure) higher than on the control, while the differences among the individual fertilization treatments were not significant (Table 3). A similar trend was observed in the total number of flowers per plant: a significantly higher number of flowers were recorded on fertilized plots, while the differences among the individual fertilization treatments were not significant. In the $2^{\text {nd }}$ fruiting year, a number of flowers significantly higher than on the control were obtained only on farmyard manure treated plots, but the total strawberry yield did not differ significantly from the control. In both years, the total number of flowers and yield was significantly higher on polyethylene mulched plots than on straw mulched plots. During the two years, average berry weight did not differ significantly between the treatments or mulching methods (Table 3).

Concentrations of available $\mathrm{P}$ (with all fertilizer treatments) and $\mathrm{K}$ (farmyard manure treatment) were significantly higher than in the control for three consecutive years of the research. At the same time the differences in the yield in the $2^{\text {nd }}$ fruiting year were not significant, so it can be concluded that $\mathrm{N}$ content in the soil was a limiting factor in increasing yield in 2011. Acuna-Maldonado and Pritts (2008) have indicated that perennial strawberry plants use $\mathrm{N}$ uptaken in the autumn to form flowers and develop flowers and berries the following year. In the

Table 3. Total number of flowers, yield of fresh strawberries and average berry weight

\begin{tabular}{|c|c|c|c|c|c|c|}
\hline & \multicolumn{3}{|c|}{2010} & \multicolumn{3}{|c|}{2011} \\
\hline & $\begin{array}{c}\text { total number } \\
\text { of flowers } \\
\text { plant }^{-1}\end{array}$ & $\begin{array}{c}\text { yield } \\
\text { g plant } \text { pla }^{-1}\end{array}$ & $\begin{array}{c}\text { average berry } \\
\text { weight } \\
\text { g plant }^{-1}\end{array}$ & $\begin{array}{c}\text { total number } \\
\text { of flowers } \\
\text { plant }^{-1}\end{array}$ & $\begin{array}{c}\text { yield } \\
\text { g plant }^{-1}\end{array}$ & $\begin{array}{c}\text { average berry } \\
\text { weight } \\
\text { g plant }^{-1}\end{array}$ \\
\hline \multicolumn{7}{|l|}{ Fertilization } \\
\hline Control & $84.7 \mathrm{~b}$ & $0.708 \mathrm{~b}$ & $11.98 \mathrm{a}$ & $96.3 \mathrm{~b}$ & $530.1 \mathrm{a}$ & $8.83 \mathrm{a}$ \\
\hline Vermicompost & $95.3 \mathrm{a}$ & $0.826 \mathrm{a}$ & $12.54 \mathrm{a}$ & $98.3 \mathrm{ab}$ & $561.1 \mathrm{a}$ & $9.17 \mathrm{a}$ \\
\hline Mushroom compost & $93.5 \mathrm{a}$ & $0.842 \mathrm{a}$ & $12.45 \mathrm{a}$ & $100.5 \mathrm{ab}$ & $580.3 \mathrm{a}$ & $9.13 \mathrm{a}$ \\
\hline \multicolumn{7}{|l|}{ Mulching } \\
\hline Polyethylene mulch & $100.2 \mathrm{~A}$ & $0.857 \mathrm{~A}$ & $12.18 \mathrm{~A}$ & $106.4 \mathrm{~A}$ & $607.8 \mathrm{~A}$ & $9.17 \mathrm{~A}$ \\
\hline Straw mulch & $86.50 \mathrm{~B}$ & $0.760 \mathrm{~B}$ & $12.45 \mathrm{~A}$ & $93.65 \mathrm{~B}$ & $524.5 \mathrm{~B}$ & $8.88 \mathrm{~A}$ \\
\hline
\end{tabular}

Notes. Values followed by different upper- (mulching) and lowercase (fertilization) letters are statistically significantly different at $p<0.05$. Interactions mulch $\times$ fertilization were not statistically significant. 
present study, mineral $\mathrm{N}$ concentration on fertilized plots was significantly higher than on the control in the year of application of organic fertilizer (autumn 2009). It is possible that plants formed larger $\mathrm{N}$ reserves, which led to a higher number of flowers per plant in the following year and eventually to a higher yield due to a larger number of berries (as average berry weight was not significantly different from the control). This is further supported by the fact that polyethylene mulched plots, where for three years we recorded higher mineral $\mathrm{N}$ concentrations than on straw mulched plots, produced a higher yield and had a higher number of flowers per plant. Our results are in agreement with findings of Opstad et al. (2007). They reported that fertilizer utilization in relation to productivity was highest when fertilizer was available at the time of flower differentiation. Also, Strik et al. (2004) and Tagliavini et al. (2005) reported that in late autumn, crowns and roots accumulate significant amounts of $\mathrm{N}$, which become remobilized the following spring.

\section{Conclusions}

1. The application of organic fertilizers in the amounts equivalent to $170 \mathrm{~kg} \mathrm{ha}^{-1} \mathrm{~N}$ had a positive effect on the concentration of mineral forms of $\mathrm{N}$ in the soil only in the year of application and the following spring, while available $P$ concentration two years after application was significantly higher on fertilized plots than on the control (27-40\% depending on fertilizer treatments).

2. The application of farmyard manure resulted in a significantly higher $\mathrm{K}$ concentration in the soil, which remained $24.5 \%$ higher than the control throughout two-year strawberry cultivation period, whereas the application of compost had a considerably weaker effect (10.4-15.5\%). Also, farmyard manure application had a beneficial effect on the concentrations of available forms of $\mathrm{Fe}, \mathrm{Zn}$ and $\mathrm{Cu}$ only in the year of application, and the application of composts (mushroom compost and vermicompost) did not affect available micronutrients concentrations in the soil.

3. Mineral $\mathrm{N}$ concentrations at all sampling times during the two years of the research were significantly higher on plots mulched with black polyethylene than on straw mulched plots, while available P concentrations were significantly higher on polyethylene mulched plots only at one sampling time. Available K concentrations did not depend on the mulch type.

4. The application of organic fertilizers led to a significant increase in yield from $16.6 \%$ to $21.1 \%$ in comparison to the control only in the $1^{\text {st }}$ fruiting year, while the application of polyethylene mulch significantly increased strawberry yield in relation to straw mulch for $12.7 \%$ in the $1^{\text {st }}$ and $15.8 \%$ in the $2^{\text {nd }}$ fruiting year.

\section{Acknowledgments}

This work was supported by the Ministry of Education, Science and Technological Development of the Republic of Serbia (project TR 31027) and partly by the Norwegian Ministry for Foreign Affairs, BalkanHERD program (project Agricultural adaptation to climate change).

Received 04042013

Accepted 19092013

\section{References}

Acuna-Maldonado L. E., Pritts M. P. 2008. Carbon and nitrogen reserves in perennial strawberry affect plant growth and yield. Journal of the American Society for Horticultural Science, 133 (6): 735-742

Chang E. H., Chung R. S., Tsai Y. H. 2007. Effect of different application rates of organic fertilizer on soil enzyme activity and microbial population. Soil Science and Plant Nutrition, 53: 132-140 http://dx.doi.org/10.1111/j.1747-0765.2007.00122.x

Council Directive 91/676/EEC of 12 December 1991 concerning the protection of waters against pollution caused by nitrates from agricultural sources

Dao T. H., Schwartz R. C. 2010. Mineralizable phosphorus, nitrogen, and carbon relationships in dairy manure at various carbon-to-phosphorus ratios. Bioresource Technology, 101: 3567-3574 http://dx.doi.org/10.1016/j.biortech.2009.12.070

De Neve S., Saez S. G., Chaves-Daguilar B., Sleutel S., Hofman G. 2004. Manipulating N mineralization from high $\mathrm{N}$ crop residues using on- and off-farm organic materials. Soil Biology and Biochemistry, 36: 127-134 http://dx.doi.org/10.1016/j.soilbio.2003.08.023

Eghball B. 2000. Nitrogen mineralization from field-applied beef cattle feedlot manure or compost. Soil Science Society of America Journal, 64: 2024-2030 http://dx.doi.org/10.2136/sssaj2000.6462024x

Eghball B., Power J. F., Gilley J. E, Doran J. W. 1997. Nutrient, carbon, and mass loss of beef cattle feedlot manure during composting. Journal of Environmental Ouality, 26: 189-193 http://dx.doi.org/10.2134/ jeq1997.00472425002600010027x

Ghosh P. K., Daval D., Bandyopadhyay K. K., Mohanty M. 2006. Evaluation of straw and polythene mulch for enhancing productivity of irrigated summer groundnut. Field Crops Research, 99: 76-86 http://dx.doi.org/10.1016/j.fcr.2006.03.004

Ginting D., Kessavalou A., Eghball B., Doran J. W. 2003. Green-house gas emissions and soil indicators four years after manure and compost applications. Journal of Environmental Quality, 32: 23-32 http://dx.doi.org/10.2134/jeq2003.2300

Grandy A. S., Porter G. A., Erich M. S. 2002. Organic amendment and rotation crop effects on the recovery of soil organic matter and aggregation in potato cropping systems. Soil Science Society of America Journal, 66: 1311-1319 http://dx.doi.org/10.2136/sssaj2002.1311

Gutser R., Ebertseder Th., Weber A., Schraml M., Schmidhalter U. 2005. Short-term and residual availability of nitrogen after long-term application of organic fertilizers on arable land. Journal of Plant Nutrition and Soil Science, 168: 439-446 http://dx.doi.org/10.1002/jpln.200520510

Hansen E. M., Thomsen I. K, Hansen M. N. 2004. Optimizing farmyard manure utilization by varying the application time and tillage strategy. Soil Use and Management, 20 (2): 173-177 http://dx.doi.org/10.1079/SUM2004242

Johnson M. S., Fennimore S. A. 2005. Weed and crop response to colored plastic mulches in strawberry production. HortScience, 40 (5): 1371-1375

Leita L., De Nobili M., Mondini C., Muhlbachova G., Marchiol L., Bragato G., Contin M. 1999. Influence of inorganic and organic fertilization on soil microbial biomass, metabolic quotient and heavy metal bioavailability. Biology and Fertility of Soils, 28: 371-376 http://dx.doi.org/10.1007/s003740050506

Li S. X., Wang Z. H., Li S. Q., Gao Y. J., Tian X. H. 2013. Effect of plastic sheet mulch, wheat straw mulch, and maize growth on water loss by evaporation in dryland areas of China. Agricultural Water Management, 116: 39-49 http://dx.doi.org/10.1016/j.agwat.2012.10.004 
Mohammadi S., Kalbasi M., Shariatmadari H. 2009. Cumulative and residual effects of organic fertilizer application on selected soil properties, water soluble P, Olsen-p and $\mathrm{P}$ sorption index. Journal of Agricultural Science and Technology, 11: 487-497

Moreno M.M., MorenoA. 2008. Effect of different biodegradable and polyethylene mulches on soil properties and production in a tomato crop. Scientia Horticulturae. 116 (3): 256-263 http://dx.doi.org/10.1016/j.scienta.2008.01.007

Motavalli P. P., Kelling K. A., Converse J. C. 1989. First year nutrient availability from injected dairy manure. Journal of Environmental Oualitv. 18: 180-185 http://dx.doi.org/10.2134/jeq1989.00472425001800020009x

Neuweiler R., Bertschinger L., Stamp P., Feil B. 2003. The impact of ground cover management on soil nitrogen levels, parameters of vegetative crop development, yield and fruit quality of strawberries. European Journal of Horticultural Science, 68 (4): 183-191

Obalum S. E., Obi M. E. 2010. Physical properties of a sandy loam Ultisol as affected by tillage-mulch management practices and cropving svstems. Soil and Tillage Research, 108: 30-36 http://dx.doi.org/10.1016/j.still.2010.03.009

Opstad N., Nes A., Mage F. 2007. Preplant fertilization and fertigation in strawberry (Fragaria $\times$ ananassa Duch. cv. 'Korona') in an open field experiment. European Journal of Horticultural Science, 72 (5): 206-213

Pansu M., Thuries L. 2003. Kinetics of C and N mineralization, $\mathrm{N}$ immobilization and $\mathrm{N}$ volatilization of organic inputs in soil. Soil Biology and Biochemistry. 35: 37-48 http://dx.doi.org/10.1016/S0038-0717(02)00234-1

Richards J., Zhang H., Schroder J., Hattey J., Raun W., Payton M. 2011. Micronutrient availability as affected by the long-term application of phosphorus fertilizer and organic amendments. Soil Science Society of America Journal, 75: 927-939 http://dx.doi.org/10.2136/sssaj2010.0269
Smith K. A., Brewer A. J., Crabb J., Dauven A. 2001. A survey of the production and use of animal manures in England and Wales. III. Cattle manures. Soil Use and Management, 17: 77-87 http://dx.doi.org/10.1111/j.1475-2743.2001.tb00012.x

Strik B., Righetti T., Buller G. 2004. Influence of rate, timing, and method of nitrogen fertilizer application on uptake and use of fertilizer nitrogen, growth, and yield of Junebearing strawberry. Journal of the American Society for Horticultural Science, 129: 165-174

Tagliavini M., Baldi E., Lucchi P., Antonelli M., Sorrenti G., Baruzzi G., Faedi W. 2005. Dynamics of nutrients uptake by strawberry plants (Fragaria $\times$ ananassa Duch.) grown in soil and soilless culture. Euronean Journal of Agronomy, 23: 15-25 http://dx.doi.org/10.1016/j.eja.2004.09.002

Wehrmann J., Scharpf H. C. 1979. Mineral nitrogen in soil as an indicator for nitrogen fertilizer requirements $\left(\mathrm{N}_{\min }{ }^{-}\right.$ method). Plant and Soil. 52: 109-126 (in German) http://dx.doi.org/10.1007/BF02197737

Wen G., Winter J. P., Voroney R. P., Bates T. E. 1997. Potassium availability with application of sewage sludge, and sludge and manure compost in field experiments. Nutrient Cycling in Agroecosystems. 47: 233-241 http://dx.doi.org/10.1007/BF01986278

Zaller J. G., Koepke U. 2004. Effects of traditional and biodynamic farmyard manure amendment on yields, soil chemical, biochemical and biological properties in a long term field experiment. Biology and Fertility of Soils. 40: 222-229 http://dx.doi.org/10.1007/s00374-004-0772-0

Zeng S. C., Su Z. Y., Chen B. G., Wu Q. T., Ouyang Y. 2008. Nitrogen and phosphorus runoff losses from orchard soils in South China as affected by fertilizer depths and rates. Pedosphere. 18: 45-53

http://dx.doi.org/10.1016/S1002-0160(07)60101-5

ISSN 1392-3196 / e-ISSN 2335-8947

Zemdirbyste-Agriculture, vol. 101, No. 1 (2014), p. 67-74

DOI 10.13080/z-a.2014.101.009

\title{
Mulčio rūšies ir tręšimo mèšlu bei kompostais įtaka braškès (Fragaria $\times$ ananassa Duch.) derlingumui ir dirvožemio savybẻms
}

\author{
R. Cabilovski ${ }^{1}$, M. Manojlovic ${ }^{1}$, D. Bogdanovic ${ }^{1}$, N. Magazin ${ }^{1}$, Z. Keserovic ${ }^{1}$, B. Sitaula ${ }^{2}$ \\ ${ }^{1}$ Serbijos Novi Sad universitetas \\ ${ }^{2}$ Norvegijos gyvybès mokslų universitetas
}

\begin{abstract}
Santrauka
Tyrimo metu siekta nustatyti organinių trąšų - méšlo, vermikomposto, grybų komposto - įtaką maisto medžiagų kiekiui dirvožemyje ir braškių derliui dvejų metų auginimo ciklo metu naudojant dvi dirvos dangas (juodą polietileną ir kviečių šiaudų mulčią). Tręšimas $170 \mathrm{~kg} \mathrm{ha}^{-1} \mathrm{~N}$ organinèmis trąšomis turejjo didžiausią įtaką judraus fosforo kiekiui, kuris buvo žymiai didesnis tręštuose laukeliuose net dvejus metus po tręšimo, palyginus su kontroliniu laukeliu. Laukeliuose, tręštuose mėšlu ir grybų kompostu, nustatytas didesnis judriojo kalio kiekis, palyginus su kontroliniu laukeliu. Tręšimas vermikompostu neturejo įtakos judriojo kalio kiekiui dirvožemyje. Tręšimas kompostais neturejjo įtakos judriųjų mikroelementų koncentracijai dirvožemyje, o $\mathrm{Fe}, \mathrm{Zn}$ ir $\mathrm{Cu}$ koncentracijos tais metais, kai tręšta organinèmis trąšomis, buvo žymiai didesnès mėšlu tręštuose laukeliuose, palyginus su kontroliniu laukeliu. Tręšimas visomis trimis organinemmis trąšomis turejjo didelę ịtaką mineralinio N koncentracijai tręšimo metais ir kitą pavasarị. Tačiau laukeliuose, uždengtuose polietileno mulčiu, visų mėginių ėmimo atvejais nustatytas didesnis mineralinio N kiekis, palyginus su kontroliniu laukeliu. Judriųjų mikroelementų koncentracija buvo žymiai didesnè dirvožemyje, dengtame juodo polietileno mulčiu, palyginus su dengtu šiaudų mulčiu. Braškes prieš sodinimą patręšus organinèmis trą̌somis, jų derlius padidèjo nuo 14,3 \% patręšus vermikompostu iki 17,3 \% patręšus mèšlu tik pirmaisiais derejjimo metais, palyginus su kontroliniu laukeliu. Tačiau polietileno mulčias lėmė didesnị braškių derlių abiem derèjimo metais, palyginus su šiaudų mulčiu.
\end{abstract}

Reikšminiai žodžiai: liekamasis poveikis, mikroelementų judrumas, organinės trąšos. 